\title{
Motif Awan (Tourism Participative Model) As an Evergreen Forest Conservation Solution in Bali Barat National Park
}

\author{
Sri Rani ${ }^{1}$, Murtafiah ${ }^{2}$, Neza Zakiyah ${ }^{3}$, Andi Irwan Benardi ${ }^{4}$ \\ \{andi@mail.unnes.ac.id\}
}

Universitas Negeri Semarang, Indonesia ${ }^{1,2,3,4}$

\begin{abstract}
Bali Barat National Park is the only National Park in the Province of Bali. located between $08^{\circ} 05^{\prime} 30^{\prime \prime} \mathrm{LS}-08^{\circ} 17^{\prime} 20^{\prime \prime} \mathrm{LS}$ dan $114^{\circ} 26^{\prime} 00^{\prime \prime} \mathrm{BT}-114^{\circ} 56^{\prime} 30^{\prime \prime}$ BT. Bali Barat National Park is one of the tourist destinations on the island of Bali which was developed as a place of research, development of science and education, supporting cultivation, tourism, and recreation. The objectives of this article include: (1) knowing the evergreen forest conditions in Bali Barat National Park, (2) knowing the conservation activities that have been carried out, and (3) knowing the contribution of Motif Awan (participatory models of tourists) in maintaining conservation. The research method used is qualitative descriptive with triangulation validity test the results showed that the evergreen forest conditions in Bali Barat National Park were good, there was little damage but not so much. Existing ecosystems can improve themselves. Conservation efforts carried out include security patrols, monitoring of Bali curves, and clean environmental actions. Community involvement in conservation efforts is successful in conservation efforts and provides optimal results. Visitor participation is needed to maintain the Bali Barat National Park Area, especially in relation to waste and ecosystem sustainability.
\end{abstract}

Keywords: Motif Awan, Conservation, Evergreen Forest.

\section{Introduction}

The existence of endemic flora and fauna in Bali is threatened with extinction because forest ecosystems as a place to live experience problems related to sustainability so conservation efforts are needed. One of the forests in Bali that is carried out for the conservation of protected animals and plants is green forests. This forest is included in the area of West Bali National Park (TNBB). The area of West Bali National Park is 19,002.89 ha and in 2005 the forest area was only 5-10 thousand ha (Alramadona: 2013). With this significant decline, it is necessary to preserve forest areas, one of which is Evergreen Forest. Besides bayur, plants protected in the National Park are Bungur (ketangi), sandalwood, candlenut, sapodilla kecik and sonokeling [1].

The protected fauna is the mascot of West Bali National Park, Bali Jalak, which in 2006 only had 6 Bali Starlings. Other interesting fauna according to research by Riyanto and Mumpuni [2] in West Bali National Park are animals included in the herpetofauna. Herpetofauna is a group of animals consisting of Amphibians and Reptiles. This group has unique and attractive causes both in terms of morphology, color, sound and behavior. One way to preserve the preservation of these rare animals and plants is to make efforts to preserve their ecosystems, one of which is the evergreen forest. 
Given the importance of conserving green forests to preserve plants, animals and to support oxygen requirements for humans, efforts are needed to maintain green forest areas. One of the conservation models that can be done is the Tourist Participation Model, namely by involving tourists directly to preserve the forest by following a tree planting program or clean environmental action for tourists visiting the National Park. The number of tourists visiting the National Park is relatively large, as can be seen from the number of tourists visiting in 2017 as many as 60,027 people (document TNBB, 2018). By implementing a participatory model, it is expected that tourists can help preserve green forests and are more interested in visiting green areas in West Bali National Park.

\section{Research Method}

This type of research is qualitative research. According to Sugiyono [3] qualitative research is a method based on philosophy of pospositivism which is used to examine the condition of ilamiah objects, where researchers are key instruments, the variables in this study are participatory tourists while the population in this study are tourists visiting TNBB. Data collection techniques using documentation, observation and interviews. Data validity test uses triangulation. Triangulation is defined as a data collection technique that combines various existing data collection techniques and data sources [3].

Research instruments in the form of interview guidelines, observation guidelines, and documentation guidelines. The method used in this research is descriptive method. Descriptive method is a method used to explain the condition of the system of thought or events in the present. Basically, this study aims to describe the data obtained from informants in the field in the form of participation from tourists to support conservation in TNBB. The data obtained in this study are then processed to produce data reduction. Reducing data means summarizing and presenting data in the form of short descriptions which then draw conclusions and verification. The research steps can be seen in the following chart:

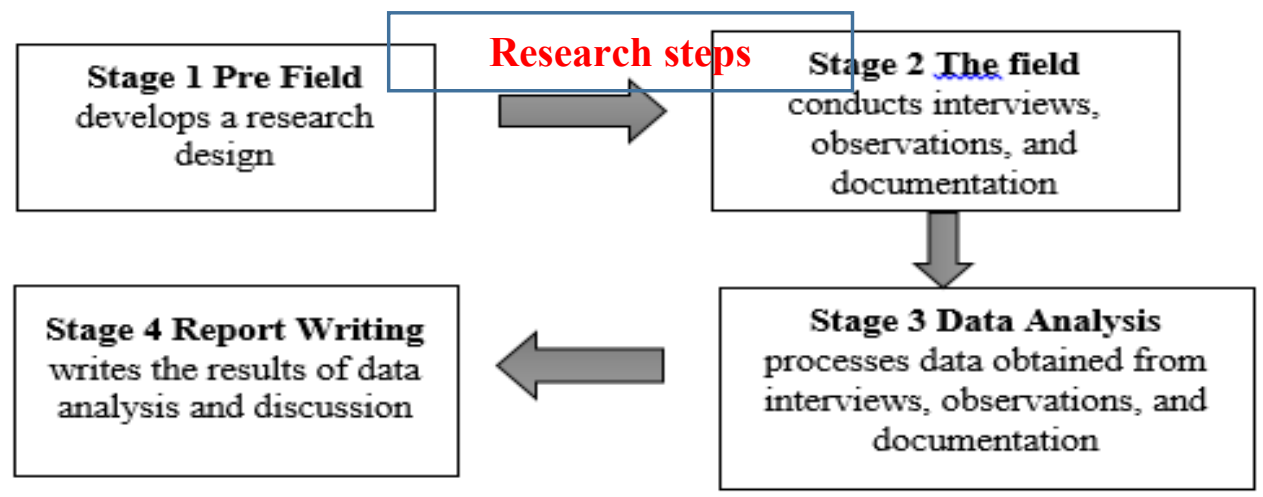




\section{Result and Discussion}

\subsection{Profile of West Bali National Park}

West Bali National Park is the only National Park in the province of Bali located in two districts, namely Buleleng and Jembrana Regencies. Balai TNBB is determined based on Minister of Forestry Decree Number: SK.2849 / Menhut-VII / KUH / 2014 concerning Forest Areas in the West Bali Forest Group (RTK 19), where the total area of the National Park is 19,026.97 ha. West Bali National Park is a type A National Park Hall consisting of TU (Administrative) sub-sections; SPTN (National Park Management Section) Region 1, Region 2; and Regional functional office groups 3. Geographically, West Bali National Park is located between 08-05 '30' LS to 08 '17' 20 'LS and 114' 26 '00' BT to 114 '56' 30 'BT. The boundaries of North West Bali National Park are Bali, Pejarakan, and Sumber Klampok (Buleleng Regency), the eastern boundary is Pejarakan and Sumber Klampok Villages (Buleleng Regency), the western boundary is Gilimanuk and the Bali Strait, Batas Selatan is Blimbingsari Village, Ekasari Village, Melaya Village (Jembrana Regency), the southeast boundary is Blimbingsari Village, Ekasari Village, and Melaya Village (Jembrana Regency).

West Bali National Park is an area that serves as a place to conserve natural resources and ecosystems. The management concept in Resort-based West Bali National Park means that the resort which is the smallest management unit is the spearhead in the implementation of conservation of living natural resources and its ecosystem. Conservation of natural resources and ecosystems is carried out by applying the $3 \mathrm{P}$ principle, namely Protection, Conservation and Utilization. In West Bali National Park there is a National Park Management Section (SPTN) that is above the resort level. SPTN in Tamana Nasional West Bali is divided into 3, namely SPTN I, SPTN II and SPTN III, besides SPTN there are 6 resorts and 1 UPKPJB (Special Management Unit for Bali Starling Development).

\subsection{Condition of Evergreen Forest in West Bali National Park}

Biodiversity in West Bali National Park consists of several types of ecosystems, namely mangrove forests, coastal forests, seasonal forests, evergreens and savannas with a total vegetation reaching 258 plants where 14 of them are rare flora such as Bayur (Pterospermum Javanicum), Ketangi (Lagerstroemia Speciosa), Burahol (Stelechocarpus Burahol), Sandalwood (Album Santalum), and Sonokeling (Dalbergia Latifolia). Besides flora, there are 10 types of rare endangered species such as Bali Starling (Leucopsar Rothschildi), White Starling (Sturnus Melanopterus), Terucuk (Pycnonotus Goiavier), White Black Head (Threskiornis Melanocephalus), and Banteng (Bos Javanicus). In addition, there are several other types of animals such as Kijang (Muntiacus muntjak nainggolani), Weasel (Pardofelis marmorata), Pangolin (Manis javanica), Porcupine (Hystrix brachyura brachyura), and Kancil (Tragulus javanicus javanicus). Vegetation in green forests always has 71 species, including Alang-alang, Walikukun, and Mentaos. There are two types of plants, including rare plants, namely Bayur and Kemiri plants. Tropical rainforests cover the surface of the earth by $6 \%$. Of these, tropical rainforests have contributed to the demand for oxygen on earth by $40 \%$. However, the area of tropical rainforest in the world is reduced by $1-2 \%$ per year.

Green forests along the world's lungs play a role in preserving the environment and human oxygen needs. As a function of environmental sustainability, green forests always play a role in various ways including absorbing and filtering carbon dioxide levels, providing water sources, producing oxygen, living quarters with millions of flora and fauna, balancing the environment, 
and preventing global warming. West Bali National Park is the last fortress for Curik Bali which has been designated as a rare protected species. In an effort to preserve the Bali Starling TNBB in collaboration with local governments, communities and the Bali Curling Breeding Association (APCB) to carry out a mission to increase the population of Bali Starling in the wild to restore the image of TNBB as an endemic animal habitat that only exists in Bali [4].

Green forest is always one of the stops of Curik Bali. Even though it's not Curik Bali's residence, the existence of green forests always draws the Bali curve to spend some of their playing time. While the natural habitat of Curik Bali is found in seasonal forest ecosystems. So far, the condition of green forests is always good, there are problems, but it does not cause damage to the ecosystem because it is still in the category of small damage so that green forests can always improve themselves. Green forests in the West Bali National Park area fall into the forests and core zones so that not everyone can access to get there.

\subsection{Conservation conducted by West Bali National Park}

The West Bali National Park is in a good management and has implemented conservation according to the Laws and Regulations of the Minister of Environment and Forestry of the Republic of Indonesia. Conservation carried out by West Bali National Park Hall refers to Law Number 5 of 1990 concerning Conservation of Biological Resources and their Ecosystems. Conservation of living natural resources and their ecosystems is carried out through activities to protect the life support system, preserve the diversity of plant and animal species and their ecosystems, and sustainably use natural biological resources and their ecosystems. In addition to these three main functions, the management of West Bali National Park is carried out by involving the community in conservation efforts [5].

Forest protection and security is an effort to prevent and limit forest destruction, forest areas and forest products caused by human actions, livestock, fires, natural resources, pests and diseases and maintaining and protecting the rights of the state, society and individuals above forests, forest areas, forest products, investments and equipment related to forest management. In Government Regulation No. 45 of 2004 Article 5 states that the implementation of forest protection aims to safeguard forests, forest products, forest areas and the environment so that protected functions, conservation functions and production functions are achieved optimally and sustainably.

Forest conservation is carried out by guarding against human disturbances, elien species as well as from forest fires, monitoring, planting trees and patrolling. In the seasonal forest which is located in the conservation utilization zone in the form of tree planting, maintenance of trees where Curik Bali lives, and clean up. In the mangrove forest conservation activities are carried out in the form of mangrove planting and clean up. On the coral reef ecosystem conservation activities are carried out, namely clean up and patrol waters. The challenge of evergreen forest management in West Bali National Park is the guarding of alien species that can cause ecosystem changes. The activity carried out by the manager to anticipate the existence of such disturbances is to monitor and check whether there are aliens of species in evergreen forests, so the way to anticipate the spread of these plants is by cutting down the trees.

The protection function is carried out through forest security operations consisting of routine patrols, water patrols, Curik Bali monitoring patrols, fire prevention patrols and joint operations. Throughout 2017, 27 forest security operations have been carried out. Activities related to the preservation of diversity include planting mangroves and breeding Curik Bali. The preservation efforts of Curik Bali are carried out in a special unit, the Special Management Unit for Bali Starling Development (UPKPJB). The main and biggest captivity is in Tegal Bunder. Starting 
from 2012, the development of the Curik Bali population has increased. One strategy to add to the Curik Bali circulation room is by conducting regular releases every year. This activity has been carried out since 2014. The release of Curik Bali was conducted at 3 sites in the West Bali National Park Area, namely Labuan Lalang, Cekik and Teluk Terima. In 2019, the West Bali National Park Office plans to release the Bali Curik Bird in the West Bali National Park Area twice. The first release of Bali Curik Bird was held on May 22, 219 as many as 45 were carried out at several sites namely Labuan Lalang, Cekik, Teluk Brumbun and Teluk Kotal. This release is carried out to coincide with the world biodiversity (PRIVATE) in 2019.

Table Number of Curik Bali Populations in the UPKPJB

\begin{tabular}{|l|l|l|l|l|l|}
\hline No & \multicolumn{1}{|c|}{ Year } & \multicolumn{1}{|c|}{ Born } & \multicolumn{1}{|c|}{ Die } & Released & Total Number \\
\hline 1 & 2010 & 16 & 10 & 7 & 52 \\
\hline 2 & 2011 & 32 & 10 & 0 & 88 \\
\hline 3 & 2012 & 31 & 23 & 10 & 50 \\
\hline 4 & 2013 & 39 & 28 & 32 & 78 \\
\hline 5 & 2014 & 53 & 14 & 31 & 114 \\
\hline 6 & 2015 & 67 & 17 & 30 & 148 \\
\hline 7 & 2016 & 104 & 39 & 26 & 199 \\
\hline 8 & 2017 & 97 & 14 & 40 & 303 \\
\hline
\end{tabular}

While the function of sustainable use is carried out with ecotourism activities. Nature tourism developed in West Bali National Park is ecotourism, which means that the tourist attractions do not prioritize on the aspect of profit but which is the most important concern, which is according to the rules in protecting the environment and does not change anything that affects the sustainability of the area. Tourism activities in West Bali National Park involve and empower the surrounding community by establishing a Natural Tourism Services Business Forum to establish good relations between the National Park and the community. The impact of these activities is that the community participates in preserving the ecosystems of tourist attractions it manages because they feel they are benefited by the existence of these tourist attractions. One example is Karang Sewu beach tourism, whose management involves the Gilimanuk community so that they get a new job other than as fishermen, namely, to become traders and tour guides for mangrove areas by boat. The community is part of the Segara Merta Fishermen and group community group.

Other activities carried out to support ecotourism are making an e-ticketing system and eIPA (Water Utilization Permit) to increase PNBP from existing natural tourism services. Revenues from natural tourism activities in West Bali National Park can be used for other activities, especially the interests of managing the National Park and preserving Curik Bird Bali. From 2010 to 2017 the number of Non-Tax State Revenues obtained has always increased. Significant increase occurred in 2015, which amounted to 7,049,300,000 which previously amounted to $1,540,807,500$. 
Evergreen forest conservation efforts carried out by TNBB are by patrolling and monitoring invasive species of plants, namely species that are not native to the ecosystem. This is intended to identify foreign plant species (alien species) that can disrupt the sustainability of the ecosystem. Aliens are specimens of certain organisms that were not previously present in a particular habitat and then introduced to the region. Foreign plants intended here are plants that can change one component of the ecosystem both biotic and abiotic. An example is an acacia plant that absorbs a lot of water so that the amount of water decreases. When the amount of water decreases, the water needs of other plants will be disrupted. This can threaten the survival of other plants, especially the typical vegetation in evergreen forests. Therefore, the effort taken is to cut down alien species plants.

\subsection{Contribution of Motif Awan (Tourist Participatory Model)}

In Law No. 5 of 1990 it was explained that the government in this case was the manager of the National Park area trying to direct and mobilize the community to participate in conservation efforts. The role of the community actually existed long ago before the West Bali National Park was designated as a National Park [5]. People who live in the area indirectly participate in maintaining forest areas. This is because in the teachings of Hinduism there is the concept of Tri Hita Kirana, which is the cause of happiness, one of which is to regulate the relationship between humans and the surrounding environment. Even so, in the implementation there are still some individuals who do not pay attention to the environment. They become perpetrators of forest destruction by doing illegal logging, hunting, and fishing in ways that are not true, causing damage to coral reef ecosystems.

Motif Awan (Participatory Tourist Model) is a conservation model involving tourists or visitor communities, in this case visitors to the West Bali National Park. Communities involved in efforts to support conservation are incorporated in groups. Conservation efforts involving the community were carried out starting in the 2000s aimed at reducing forest and ecosystem damage in the TNBB. People who were formerly perpetrators of destruction are now involved in tourism conservation and management activities. The activity is carried out by creating community groups with the same goal in certain activities. The community groups included the Segara Merta group engaged in the management of the sewu reef beach tour, Karang Sewu fishing community group, the West Bali Touris Transportation group, the Driver Boat Menjangan group, the composting community group "Wana Asri", and the bird breeder group "Bali Jaya Sustainable ".

Community involvement in conservation efforts was carried out in the utilization zone of the West Bali National Park with an area of 4,294, $43 \mathrm{Ha}$ or 22.6\% of the total area of West Bali National Park. The community involved in the activity were the people living in 8 buffer villages namely Gilimanuk Village, Melaya Village, Blimbingsari Village, Ekasari Village, Sumberklampok Village, and Pejarakan Village. Community involvement is carried out through several activities, namely protection and regional security patrols with the Community Forestry Partner Program, forest fire prevention through Fire Care Community activities, monitoring of Curik Bali, Mangrove planting, and community involvement in the management of tourist areas.

Community involvement in conservation efforts carried out by West Bali National Park has a positive influence. These influences can be seen from several indicators and their achievements, namely:

1) Increased number of Balinese curries 
At present, capturing Curik Bali is carried out with community-based through multistakeholder collaboration. One of the programs carried out is adoption of nesting boxes or sanctuaries (cages) in Curik Bali. The donors or partner companies of TNBB can donate money which is then allocated for the procurement of nesting boxes. While the form of cooperation with the community is carried out by creating breeders in several regions by involving community groups as managers. The breeding is in four places, namely Gilimanuk Village, there are 7 breeders managed by the community group "Jaya Bali Lestari", Blimbingsari Village, there are 4 breeders managed by "Bari Marta Paksi" and "Ekasari Bird Farm", Sumberklampok Village, there are 17 cultivators managed by "Manuk Jegeg ", and Melaya Village with 1 breeder managed by the group" Lestari Curik Bali ".

The benefits obtained from these activities are increasing the economic value of the community, increasing the population of Curik Bali both in nature and in captivity, reducing the crime of hunting Curik Bali in nature, increasing public awareness in preserving Curik Bali and its habitat, and increasing tourist attraction in the presence community-based Curik Bali ecotourism.

2) The number of forest destruction and illegal logging has decreased

To overcome the problem of forest destruction and illegal logging, the managers concerned are forest rangers conducting routine patrols by involving the community to reduce the number of cases of destruction and illegal logging. Another form of community participation is by reporting to the West Bali National Park when finding suspicious things that lead to forest destruction and illegal logging. Therefore, with routine patrols involving the community, eating can reduce the case.

\section{3) Mangrove conservation increases}

The mangrove ecosystem in West Bali National Park is one of the most complete ecosystems scattered in various places. One of the distributions is in Karang Sewu beach tourism located in Gilimanuk Village. There is a "Segara Merta" community group whose activity is to plant mangroves along the coast of Karang Sewu. In addition to planting mangroves, there are also certain tree plantations that are typical ecosystems of West Bali National Park which are planted in utilization zones such as Intersection trees.

\section{4) Better tourism management}

The existence of the community in tourist objects indirectly contributes to maintaining the cleanliness of tourist areas and security. One example of a tourist attraction developed with community involvement is the Karang Sewu beach attraction. Tourism management in West Bali National Park is one of the best. This is evidenced by the awards that have been achieved throughout 2018, namely 3 awards, one of which is an international award.

\section{5) Forest fires}

The case of forest fires that occurred in the area of West Bali National Park starting in 2009 - 2017 was caused by natural factors, namely the dry season with a wide area of burning. To overcome this, firefighters collaborated with the community through the Fire Care Community program. 
6) Clean-up activities

Clean up actions have a significant share in maintaining the cleanliness of the TNBB area. The activity is carried out once a week and on certain celebration days. The chart below is a plot of the Motif Awan model.

West Bali National Park in an effort to involve the community uses a cooperative strategy and is not rigid in addressing issues related to the community. Cooperative which is meant here is not necessarily using criminal reasons, every problem is solved in a good way and prioritizes the way of peace. This method is proven to be able to embrace various groups of society and does not cause prolonged conflict. Through community empowerment activities, they will feel that they have a West Bali National Park area and feel profitable with tourism activities so that they will indirectly safeguard the National Park area. With the existence of this program, the form of community participation in conservation efforts is structured so that the results of these efforts are more visible impact.

The Motif Awan is a model carried out by managers by involving the public and tourists in conservation efforts in TNBB. Motif Awan (Tourist Participatory Model) is a conservation model involving tourists or visitors, in this case visitors in West Bali National Park. The number of visitors in the National Park tends to increase. In general, tourist areas that have been widely known to the public will cause negative impacts such as waste and environmental damage.

\section{Schem Model of Motif Awan}

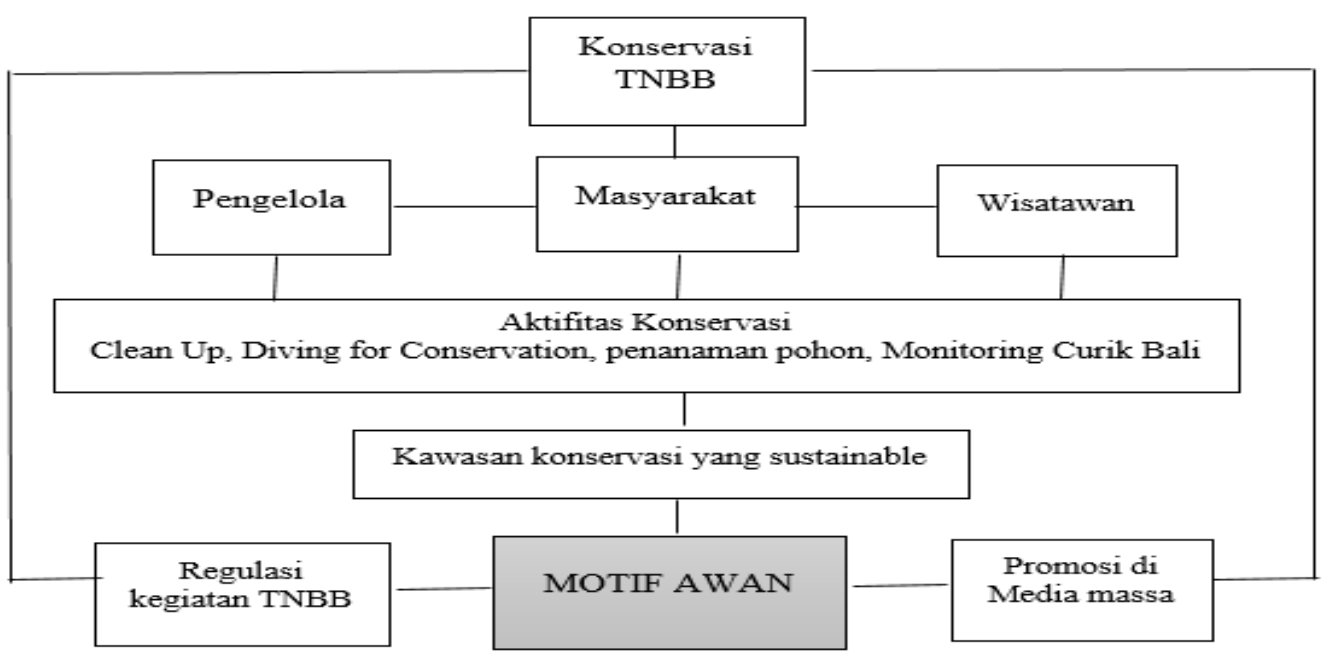

Therefore there is a need for participation from tourists and the local community. The participation referred to in this study can be in the form of energy, mind, and material. The attitude of visitors who do not dispose of litter, do not damage existing ecosystems and participate in clean environmental actions is a form of participation. 


\section{Conclusion}

1 The Motif Awan is a model carried out by managers by involving the public and tourists in conservation efforts in TNBB. Evergreen forest conditions in West Bali National Park are good, with no significant damage. Existing ecosystems can repair themselves because damage is still on a small scale.

2 Forest conservation is carried out by guarding against human disturbances, 'alien' species and from forest fires, monitoring, tree planting and regional security patrols.

3 The involvement of tourists plays a role in helping conservation efforts carried out by West Bali National Park. The community groups included the Segara Merta group engaged in the management of the sewu reef beach tour, Karang Sewu fishing community group, the West Bali Touris Transportation group, the Driver Boat Menjangan group, the composting community group "Wana Asri", and the bird breeder group "Bali Jaya Lestari ".

\section{References}

[1] "Kerja Unit Pelaksana Teknis Taman Nasional."

[2] B. Zoologi, "HERPETOFAUNA DI TAMAN NASIONAL BALI BARAT."

[3] Sugiyon, Metode Penelitian kuantitatif, kualitatif dan R\&D. Bandung: Alfabeta, 2016.

[4] I. P. G. Ardhana and N. Rukmana, "KEBERADAAN JALAK BALI (Leucopsar rothschildi Stresemann 1912) DI TAMAN NASIONAL BALI BARAT," SIMBIOSIS, pp. 1-6.

[5] U.-U. No, "Tahun 1990 tentang Konservasi Sumber Daya Alam Hayati dan Ekosistemnya," Dep. Kehutanan. Jakarta. Tanggal, vol. 10, 5AD. 